\title{
MULTICRITERIA ANALYSIS OF SELECTED BUILDING THERMAL INSULATION SOLUTIONS
}

\section{P. NOWAK ${ }^{1}$, M. SKLODKOWSKI ${ }^{2}$}

\begin{abstract}
The purpose of this paper is to present and analyse the decision-making problem faced by a future house owner - selection of the optimal solution of building thermal insulation in relation to the selected criteria, both related to costs and future benefits. The problem of selecting the best solutions in the construction sector is widely discussed in the science literature. In this paper, the authors decided to solve the raised problem by using the Entropy method.
\end{abstract}

Keywords: multicriteria decision making, building thermal insulation, Entropy.

\section{INTRODUCTION}

The purpose of this paper is to present and analyse the decision-making problem faced by a future house owner - selection of the optimal solution of building thermal insulation in relation to the selected criteria, both related to costs and future benefits. The problem of selecting the best solutions in the construction sector is widely discussed in the science literature [1], [2], [3], [4], [5], [6], [7], [8], [9], [10], [11], [12], [13]. In this paper, the authors decided to solve the raised problem by using the Entropy method. It is necessary to stress the fact that the choice of a potential investor that plans to erect a new building has long-term effects and substantial impact on future building maintenance costs. Thanks to the use of adequate roof, wall and ceiling insulation, it is possible to decrease the future heating costs by $20-40 \%$ with an approximate payback time of 10 years.

\footnotetext{
${ }^{1}$ PhD., Eng., Warsaw University of Technology, Faculty of Civil Engineering, Al. Armii Ludowej 16, 00-637 Warsaw, Poland, e-mail: p.nowak@il.pw.edu.pl

${ }^{2}$ MSc., Eng., Warsaw University of Technology, Faculty of Civil Engineering, Al. Armii Ludowej 16, 00-637 Warsaw, Poland
} 
Thanks to the use of adequate roof, wall and ceiling insulation, it is possible to decrease the future heating costs by $20-40 \%$ with an approximate payback time of 10 years. Over a dozen years ago, when building a single family house, not many people considered its thermal insulation and even less reflected on a thought-out choice and its effective execution. The last dozen years brought many restrictions in this aspect, including legal restrictions (in the form of acts, EU regulations and directives). Standards were introduced, the fulfilment of which requires separate analyses (e.g. in the form of energy certificates). Currently, the construction materials market offers newer and "better" insulation materials, which allow selecting the most adequate building thermal insulation with consideration of the characteristics and specificity of a given building.

\section{INPUT DATA FOR THE PURPOSES OF THE MULTICRITERIA ANALYSIS}

In order to conduct the multicriteria evaluation of the selected material solutions for the building thermal insulation, we used the design of a single family house as the so called "model structure". We estimated the cost of execution of thermal insulation for the house's parameters, which constitutes one of the selection criteria.

Table 1. Specification of compartments of the analysed house

\begin{tabular}{|c|c|c|}
\hline \multirow{2}{*}{ No. } & $\begin{array}{c}\text { Construction } \\
\text { element }\end{array}$ & Area $_{\text {calculated }}\left[\mathbf{m}^{\mathbf{2}}\right]$ \\
\cline { 3 - 3 } & $\mathbf{m}^{\mathbf{2}}$ \\
\hline $\mathbf{1}$ & External window & 54.6 \\
\hline $\mathbf{2}$ & External wall & 138.82 \\
\hline $\mathbf{3}$ & External door & 5.04 \\
\hline $\mathbf{4}$ & External ceiling & 106.8 \\
\hline $\mathbf{5}$ & Roof & 59.16 \\
\hline
\end{tabular}

The analysis included options of material solutions for external walls and roof insulation. Table 2 presents the specification of basic materials (without insulation materials, which are the subject of the analysis) from which the compartments are designed. The compartments do not include materials which are irrelevant for the estimation of the $U$ coefficient (e.g. internal and external plaster). In the latter part of the paper, the $U_{c}$ coefficient value will used to estimate the minimum thickness of the thermal insulation layer. 
Table 2. Specification of materials used for designing the compartments

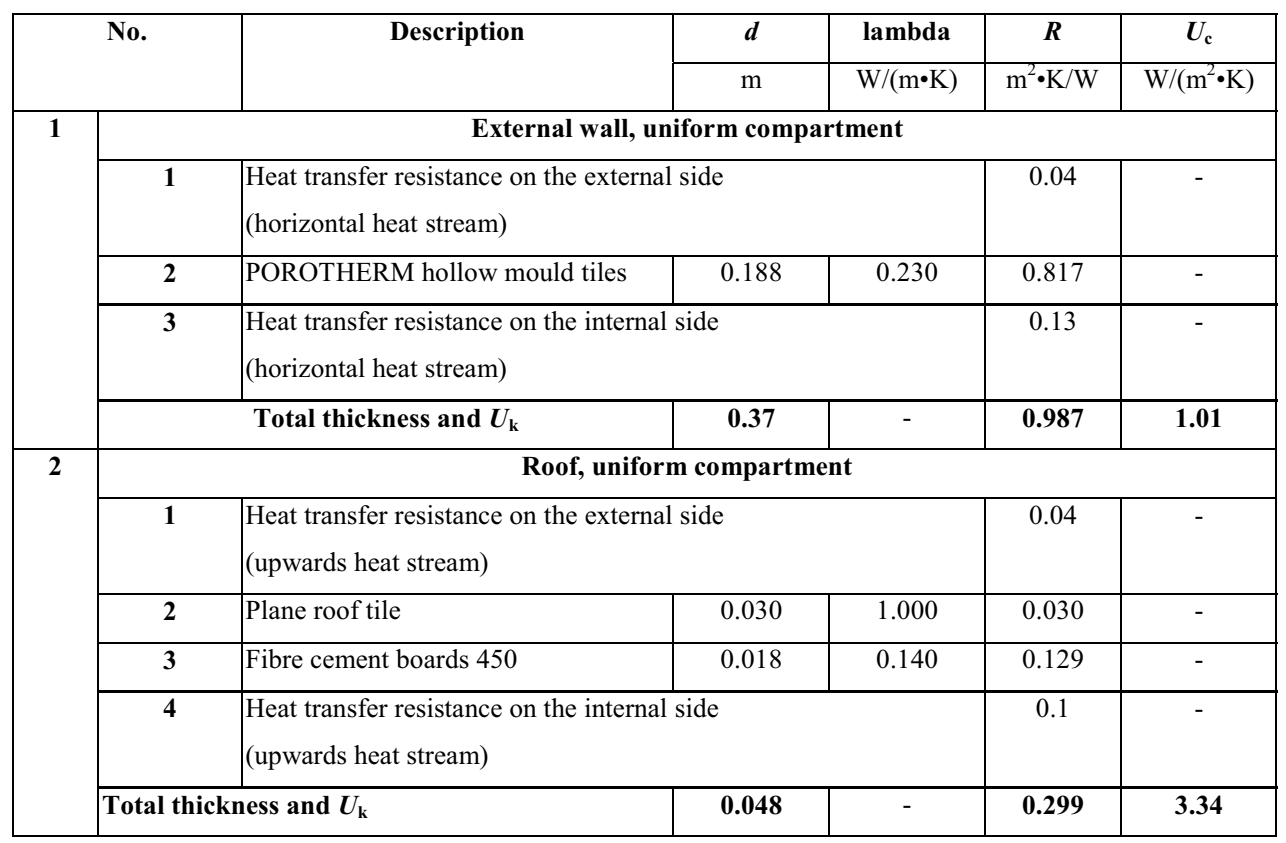

\section{DECISION-MAKING PROBLEM}

The basic criterion in the case of all methods supporting the decision-making is the correct formulation of the decision-making problem [4], [7], [8]. The authors have defined the following, amongst others, for the raised problem:

- decision-maker,

- conditions limiting the decision,

- set of acceptable decisions,

- evaluation criteria and degrees of their significance.

The paper assumed the comparison of four material solutions for the executed construction works: mineral wool $(\mathrm{O} 1)$, polyurethane $(\mathrm{O} 2)$, expanded polysterene $(\mathrm{O} 3)$, phenolic resole board $(\mathrm{O} 4)$.

The decision-making criteria have been chosen so that one criterion does not directly depend on another (high assessment of one of them causes an increase in the assessment of another). Furthermore, the criteria have been defined and described as accurately as possible, so that the evaluation by third persons is as explicit as possible. This problem does not occur in the case 
of measurable criteria (the option evaluation gives us a specific numerical value), such as the cost, time of execution, etc. The problem occurs when we are dealing with criteria that are hard to measure (such as aesthetics, nuisance or environmental impact) [1].

The authors selected the following criteria: material thermal insulation (C1), cost of execution of insulation required to obtain the required values of the heat transfer coefficient $U(C 2)$, durability (C3), mechanical properties of the insulation (C4), environmental impact (C5), material's fire resistance (C6). Table 3 presents the specification of evaluation results for particular options in terms of the selected criteria. The matrix may not however be used for further analysis without being processed earlier.

Table 3. Matrix of evaluation results for particular options

\begin{tabular}{|c|c|c|c|c|c|c|}
\hline \multirow[b]{2}{*}{ Option } & \multicolumn{6}{|c|}{ Criteria } \\
\hline & $\begin{array}{c}\mathbf{K} 1 \\
{[\mathbf{W} /(\mathbf{m} * \mathbf{K})]}\end{array}$ & $\begin{array}{c}\text { K2 } \\
{[\mathrm{PLN}]}\end{array}$ & $\begin{array}{c}\text { K3 } \\
\text { [points] }\end{array}$ & $\begin{array}{c}\mathrm{K} 4 \\
\text { (average compression and tensile } \\
\text { strength at relative deformation of } 10 \% \\
{[\mathrm{kPa}] \text { ) }}\end{array}$ & $\begin{array}{c}\text { K5 } \\
\text { (total } \\
\text { energy } \\
\text { used }[\mathbf{M J}])\end{array}$ & $\begin{array}{c}\text { K6 } \\
\text { [points] }\end{array}$ \\
\hline W1 & 0.038 & $23,850.30$ & 8 & 12.5 & $76,040.99$ & 13 \\
\hline $\mathbf{W} 2$ & 0.022 & $24,843.53$ & 9 & 190 & $61,123.23$ & 8 \\
\hline W3 & 0.036 & $23,896.94$ & 7 & 85 & $40,515.61$ & 4 \\
\hline W4 & 0.023 & $51,855.84$ & 10 & 115 & $54,470.57$ & 11 \\
\hline
\end{tabular}

All algorithms of the multicriteria analysis are susceptible to whether the criteria are "positive" (stimulants) or "negative" (destimulants). In the presented studies, the "positive" criteria include C3 (durability), C4 (mechanical properties), C6 (fire resistance), while the other criteria are "negative" (cost, environmental impact and the heat transfer coefficient). They were interchanged by presentation in a reversed form (1/evaluation value). Then, the results have undergone the vector (Euclidean) normalisation in accordance with the following formula (3.1):

$$
A_{v_{i, j}}=\frac{A_{0_{i, j}}}{\sqrt{\sum_{i}\left(A_{0_{i, j}}\right)^{2}}}
$$

The final specification of evaluations of particular options after normalisation is presented in table 4. 
Table 4. Final specification of evaluations of particular options after normalisation

\begin{tabular}{|c|c|c|c|c|c|c|}
\hline \multirow{2}{*}{ Option } & \multicolumn{6}{|c|}{ Criteria } \\
\cline { 2 - 7 } & K1 & K2 & K3 & K4 & K5 & K6 \\
\hline W1 & 0.3574 & 0.5653 & 0.4666 & 0.0525 & 0.3531 & 0.6758 \\
\hline W2 & 0.6174 & 0.5427 & 0.5249 & 0.7979 & 0.4393 & 0.4159 \\
\hline W3 & 0.3773 & 0.5642 & 0.4082 & 0.3569 & 0.6628 & 0.2080 \\
\hline W4 & 0.5905 & 0.2600 & 0.5832 & 0.4829 & 0.4930 & 0.5719 \\
\hline
\end{tabular}

\section{ENTROPY METHOD}

The authors used the Entropy method to find the best options. This method allows estimation of the significance of the analysed options, used in the evaluation of the selected options, solution of the raised decision-making problem based on the discrepancies in the value of each of them. The first person to use the entropy method in information theory was Cloude Shannon and then it was perfected by B. MacMillan and L. Breiman [4].

In this method, the final stage of the estimation algorithm, used to obtain the preferred order of particular options, uses the following elements:

- Degrees of criteria fulfilment determined subjectively by the decision-maker (expert),

- Degrees of criteria fulfilment obtained on the basis of the estimation procedure.

The first step of the Entropy method is to break down the results of the evaluation of options alongside further criteria, so that each of the criteria is a stimulant. We have obtained this by presenting criterion 2 and 5 as inverse elements of the initial evaluations (table 5).

Table 5. D results matrix

\begin{tabular}{|c|c|c|c|c|c|c|}
\hline \multirow{2}{*}{ Option } & \multicolumn{6}{|c|}{ Criteria } \\
\cline { 2 - 7 } & $\mathbf{K 1}$ & K2 & K3 & K4 & K5 & K6 \\
\hline W1 & 26.31 & 0.0000419281864 & 8 & 12.5 & 0.0000131508010 & 13 \\
\hline W2 & 45.45 & 0.0000402519284 & 9 & 190 & 0.0000163603930 & 8 \\
\hline W3 & 27.77 & 0.0000418463546 & 7 & 85 & 0.0000246818460 & 4 \\
\hline W4 & 43.47 & 0.0000192842313 & 10 & 115 & 0.0000183585370 & 11 \\
\hline
\end{tabular}


The next step is to subject the matrix D to the normalisation procedure according to formula (4.1) [7].

$$
p_{i j}=\frac{d_{i j}}{\sum d_{i j}}
$$

Thus, we obtained the matrix P (table 6), which will be used for further estimations.

Table 6. Entropy method's matrix P

\begin{tabular}{|c|c|c|c|c|c|c|}
\hline \multirow{2}{*}{ Option } & \multicolumn{6}{|c|}{ Criteria } \\
\cline { 2 - 7 } & $\mathbf{C 1}$ & $\mathbf{C 2}$ & $\mathbf{C 3}$ & $\mathbf{C 4}$ & $\mathbf{C 5}$ & $\mathbf{C 6}$ \\
\hline $\mathbf{O 1}$ & 0.183986 & 0.292568428 & 0.235294 & 0.031056 & 0.181261408 & 0.361111 \\
\hline $\mathbf{O 2}$ & 0.317832 & 0.280871758 & 0.264706 & 0.47205 & 0.225500171 & 0.222222 \\
\hline $\mathbf{O 3}$ & 0.194196 & 0.291997418 & 0.205882 & 0.21118 & 0.340197237 & 0.111111 \\
\hline $\mathbf{O 4}$ & 0.303986 & 0.134562396 & 0.294118 & 0.285714 & 0.253041185 & 0.305556 \\
\hline
\end{tabular}

Then, particular criteria were assigned with subjective criteria significance degrees. We decided to use the first set which was applied in the Weighted Sum method, so that the results were comparable.

Table 7. Degrees of fulfilment of the Entropy method's criteria (vector $\mathrm{W}_{\mathrm{j}}{ }^{*}$ )

\begin{tabular}{|l|c|c|c|c|c|c|c|}
\hline & C1 & C2 & C3 & C4 & C5 & C6 & Total \\
\hline Weight & 0.2 & 0.35 & 0.15 & 0.1 & 0.1 & 0.1 & 1 \\
\hline
\end{tabular}

According to the estimation procedure, the next step is the estimation of the value of entropy $E_{j}$ according to formula (4.2). The estimation results are presented in table no. 8 .

$$
E_{j}=-k \sum p_{i j} \ln \left(p_{i j}\right)
$$

Table 8. Specification of the Entropy level (vector $\mathrm{E}_{\mathrm{j}}$ )

\begin{tabular}{|c|c|c|c|c|c|c|}
\hline Criterion & E1 & E2 & E3 & E4 & E5 & E6 \\
\hline Ej1 & 0.757 & 0.751 & 0.769 & 0.641 & 0.759 & 0.730 \\
\hline
\end{tabular}


Then, it is necessary to estimate the Entropy variability, which is presented in table no. 9.

Table 9. Entropy variability $\left(\right.$ vector $\left.\mathrm{d}_{\mathrm{j}}\right)$

\begin{tabular}{|c|c|c|c|c|c|c|}
\hline Criterion & d1 & d2 & d3 & d4 & d5 & d6 \\
\hline $\mathbf{d}_{\mathbf{j}}$ & 0.243 & 0.249 & 0.231 & 0.359 & 0.241 & 0.270 \\
\hline
\end{tabular}

Then, by using formulae (4.3) and (4.4) respectively, it is necessary to estimate values $\mathrm{W}_{\mathrm{j}}{ }^{0}$ and $\mathrm{W}_{\mathrm{j}}$, the results of which are presented in table no. 10 .

$$
w_{j}^{0}=\frac{w_{j} w_{j}^{*}}{\sum w_{j} w_{j}^{*}}
$$

Where $w_{j}^{*}$ - subjectively determined criteria weights, whereas:

$$
w_{j}=\frac{d_{j}}{\sum d_{j}}
$$

\begin{tabular}{|c|c|c|c|c|c|c|c|}
\hline & & & & & & & total \\
\hline $\mathbf{W j}$ & 0.153 & 0.156 & 0.145 & 0.225 & 0.151 & 0.169 & 1 \\
\hline $\mathbf{W} \mathbf{j}^{*}$ & 0.2 & 0.35 & 0.15 & 0.1 & 0.1 & 0.1 & 1 \\
\hline $\mathbf{W j}^{\mathbf{0}}$ & 0.189 & 0.339 & 0.135 & 0.139 & 0.094 & 0.105 & 1 \\
\hline
\end{tabular}

Table 10. Specification of weight values (vectors $\mathrm{W}_{\mathrm{j}}, \mathrm{W}_{\mathrm{j}}{ }^{*}, \mathrm{~W}_{\mathrm{j}}^{0}$ respectively)

Vector $\mathrm{W}_{\mathrm{j}}{ }^{0}$ is the vector of the "new" criteria fulfilment degrees and it will be used to estimate the final result (solutions vector $C_{j}$ ), which will then be used to designate the order of the preferred solutions. The value of vector $C_{j}$ was estimated from formula (4.5).

$$
c_{j}=\sum d_{i j} w_{j}^{0}
$$

The following results have been obtained for particular options: $\mathrm{O} 1=0.225, \mathrm{O} 2=0.301 ; \mathrm{O} 3=0.236$, $\mathrm{O} 4=0.238$ (vector $\mathrm{C}_{\mathrm{j}}$ ). The order of the preferred solutions was obtained by arranging the solutions vector in a decreasing order. The most preferred option turned out to be option O2 (PUR foam thermal insulation). 
The least preferred option turned out to be option $\mathrm{O} 1$ (mineral wool thermal insulation). In the case of the Entropy method, it is clear that a change in one criterion caused a substantially lesser change in the final order result. This means that the method assigns less significance to weights selected subjectively by the decision-maker. This also means that the method allows obtaining more subjective results.

\section{ConCLUSIONS}

As result of the conducted multicriteria evaluation of the options it was assumed that the most adequate thermal insulation system for a single family house is thermal insulation with polyurethane foam, while the least adequate (worst) - according to the Entropy method - thermal insulation with mineral wool.

In the authors' opinion, the applied methods of multicriteria evaluation improve the decisionmaking process, because they allow arrangement of the set of considered solutions and selection of the best option in the light of the adopted evaluation criteria.

Furthermore, the multicriteria decision-making models constitute the most versatile tool of multicriteria evaluation and can be recommended as the best relative tool for solving the tough problem of evaluation.

It is of course hard to clearly determine which of the multicriteria evaluation methods is better and more suitable for the given decision-making task, because the evaluation difficulty results mainly from the degree of complexity of the decision-making task, complexity of options and preferences of the evaluator.

The applied methods allowed to obtain various arrangement of options, resulting mainly from the specificity of the given estimation algorithm. 


\section{REFERENCES}

1. N. Ibadov, "Wielokryterialny wybór wariantów wykonania przedsięwzięć budowlanych na podstawie rozmytej relacji preferencji”. Logistyka 6/2014, Pełny tekst na CD3 str. 4564-4569.

2. N. Ibadov, "Wielokryterialna ocena procesów budowlanych z uwzględnieniem rozmytego modelowania niepewności aspektów technologicznych". Autobusy (ISSN 1509-5878): Technika, Eksploatacja, Systemy transportowe 2013, nr 3. Tom 14, Str. 1183-1191.

3. M. Kaftanowicz, M. Krzemiński, "Multiple-criteria analysis of plasterboard systems", Procedia Engineering 111, 2015: 364-370.

4. M. Krzemiński, M. Książek, P. Nowak, J. Rosłon, T. Wieczorek, "Wielokryterialna ocena wybranych rozwiązań konstrukcyjnych ścian w aspekcie odporności ogniowej“, Logistyka, 2014, vol. 5, pages: 862-871, ISSN 1231-5478.

5. M. Książek, P. Nowak, "Expert methods for design solutions assessment”, Logistyka 2009, nr 6.

6. M. Książek, P. Nowak, S. Kivrak, J. Rosłon, L. Ustinovichius: "Computer-aided decision-making in construction project development“, Journal of Civil Engineering and Management, 2015, vol. 21 (2), pages: 248-259, ISSN 1392-3730.

7. M. Książek, P. Nowak, J. Rosłon, "Ocena wielokryterialna wybranych rozwiązań konstrukcyjnych stropów“, Logistyka, 2014, vol. 6, ISSN 1231-5478.

8. M. Książek, P. Nowak, J. Rosłon, T. Wieczorek, "Multicriteria Assessment of Selected Solutions for the Building Structural Walls“, XXIII R-S-P seminar, Theoretical Foundation of Civil Engineering (23RSP), Procedia Engineering, 2014, vol. 91, pages: 406-411, ISSN: 1877-7058.

9. Radziszewska-Zielina E., Szewczyk B., "Controlling partnering relations in construction operations using fuzzy reasoning”, Archives of Civil Engineering, vol. LXI, is. 3, 2015, pp. 89-104.

10. Radziszewska-Zielina E., "Fuzzy control of the partnering relations of a construction enterprise", Journal of Civil Engineering and Management, Vol. 17, No. 1, 2011, pp. 5-15.

11. Radziszewska-Zielina E., "Analysis of the partnering relations of Polish", Slovak and Ukrainian construction enterprises, „Technological and Economic Development of Economy”, Vol. 16, No. 3, 2010, pp. 432-454.

12. Radziszewska-Zielina E., "Analysis of the Impact of the Level of Partnering Relations on the Selected Indexes of Success of Polish Construction Enterprises”, „Inzinerine Ekonomika-Engineering Economics”, Vol. 21, No. 3, 2010, pp. 324-335.

13. L. Ustinovichius, E. Zavadskas, D. Migilinskas, A. Malewska, P. Nowak, A. Minasowicz, "Verbal analysis of risk elements in construction contracts", Cooperative Design, Visualization, and Engineering, 295-302, 2006. 


\section{LIST OF FIGURES AND TABLES:}

Tab. 1. Specification of compartments of the analysed house

Tab. 2. Specification of materials used for designing the compartments

Tab. 3. Matrix of evaluation results for particular options

Tab. 4. Final specification of evaluations of particular options after normalisation

Tab. 5. D results matrix

Tab. 6. Entropy method's matrix P

Tab. 7. Degrees of fulfilment of the Entropy method's criteria (vector $\mathrm{W}_{\mathrm{j}}{ }^{*}$ )

Tab. 8. Specification of the Entropy level (vector $E_{j}$ )

Tab. 9. Entropy variability (vector $d_{j}$ )

Tab. 10. Specification of weight values (vectors $\mathrm{W}_{\mathrm{j}}, \mathrm{W}_{\mathrm{j}}{ }^{*}, \mathrm{~W}_{\mathrm{j}}^{0}$ respectively)

Tab. 1. Zestawienie przegród analizowanego domu

Tab. 2. Zestawienie materiałów wykorzystanych do zaprojektowania przegród

Tab. 3. Macierz wyników oceny dla poszczególnych wariantów

Tab. 4. Zestawienie końcowe ocen poszczególnych wariantów po normalizacji

Tab. 5. Macierz Wyników D

Tab. 6. Macierz P metody Entropii

Tab. 7. Stopnie spełnienia kryteriów metody Entropii (wektor $\mathrm{W}_{\mathrm{j}}{ }^{*}$ )

Tab. 8. Zestawienie poziomu Entropii (wektor $\mathrm{E}_{\mathrm{j}}$ )

Tab. 9. Zmienność Entropii (wektor $\mathrm{d}_{\mathrm{j}}$ )

Tab. 10. Zestawienie wartości wag (wektory odpowiednio $\mathrm{W}_{\mathrm{j}}, \mathrm{W}_{\mathrm{j}}{ }^{*}, \mathrm{~W}_{\mathrm{j}}{ }^{0}$ ) 


\title{
WIELOKRYTERIALNA ANALIZA WYBRANYCH ROZWIĄZAŃ OCIEPLENIA BUDYNKÓW
}

\author{
Slowa kluczowe: wielokryterialne metody podejmowania decyzji, ocieplenie budynku, entropia
}

\section{STRESZCZENIE:}

Celem niniejszego referatu jest zaprezentowanie i analiza problemu decyzyjnego, przed jakim stoi przyszły właściciel domu - wybór optymalnego rozwiązania dla izolacji termicznej budynku w odniesieniu do wybranych kryteriów, zarówno kosztowych, jak i tych uwzględniających przyszłe korzyści. Problem wyboru najlepszych rozwiązań w budownictwie podejmowany jest szeroko w literaturze naukowej. W swojej pracy, autorzy zdecydowali się na rozwiązanie postawionego problemu za pomocą metody Entropii.

Należy podkreślić fakt, ze wybór przed którym zostaje postawiony potencjalny inwestor, planujący wybudowanie nowego budynku ma długofalowe skutki i bardzo istotny wpływ na późniejsze koszty utrzymania obiektu. Dzięki zastosowaniu odpowiedniej izolacji dachu, ścian i stropów możliwe jest zmniejszenie przyszłych kosztów ogrzewania w granicach 20 - 40\% przy orientacyjnym czasie zwrotu około 10 lat. Jeszcze kilkanaście lat temu, budując dom jednorodzinny mało kto brał pod uwagę jego ocieplanie, a jeszcze mniej zastanawiano się nad przemyślanym wyborem i efektywnym jego wykonaniem. Ostatnie kilkanaście lat przyniosło wiele obostrzeń w tej kwestii, także prawnych (w postaci ustaw, rozporządzeń i dyrektyw unijnych). Wprowadzono normy, których spełnienie wymaga osobnych analiz (np.: w postaci certyfikatu energetycznego). w chwili obecnej, rynek materiałów budowlanych oferuje coraz to nowsze i „lepsze” materiały izolacyjne, umożliwiając wybór najbardziej właściwego systemu ocieplenia budynków, adekwatnie do charakterystyki i specyfiki danego obiektu budowlanego.

W celu przeprowadzenia oceny wielokryterialnej wybranych rozwiązań materiałowych dla izolacji termicznej budynku, jako tak zwany „obiekt wzorcowy” wykorzystano projekt domu jednorodzinnego. Dla parametrów tego domu wyliczony został koszt realizacji termoizolacji, który jest jednym z kryteriów wyboru.

Podstawowym kryterium w przypadku wszystkich metod wspomagających podejmowanie decyzji jest poprawne sformułowanie problemu decyzyjnego.

Dla postawionego w artykule problemu, autorzy zdefiniowali m.in.:

- decydenta,

- warunki ograniczające decyzję,

- zbiór decyzji dopuszczalnych,

- $\quad$ kryteria oceny i ich stopnie ważności;

W artykule założono porównanie czterech rozwiązań materiałowych dla przeprowadzanych robót budowlanych: wełna mineralna (W1), poliuretan (W2), styropian (W3), płyta fenolowo-rezolowa (W4).

Kryteria decyzyjne zostały dobrane w ten sposób aby jedno z kryteriów nie zależało od innego w sposób bezpośredni (wysoka ocena jednego z nich powoduje wzrost oceny drugiego). Ponadto kryteria zostały zdefiniowane i opisane możliwie najdokładniej tak aby ocena, przez osoby trzecie była w miarę możliwości jednoznaczna. Takiego problemu nie ma w przypadku kryteriów mierzalnych (ocena wariantu zwraca nam konkretną wartość liczbową), takich jak np. koszt, czas wykonania itp. Problem taki pojawia się gdy mamy do czynienia z kryteriami trudno mierzalnymi (takimi jak estetyka, uciążliwość, czy wpływ na środowisko). Autorzy zwrócili szczególną uwagę na jasny i czytelny opis kryteriów. 
Autorzy wybrali następujące kryteria: termoizolacyjność materiału (K1), koszt wykonania izolacji niezbędnej do osiągnięcia wymaganych wartości współczynnika przewodzenia ciepła U (K2), trwałość (K3), własności mechaniczne izolacji (K4), wpływ na środowisko naturalne (K5), ognioodporność materiału (K6).

Do wyłonienia najlepszych wariantów, autorzy wykorzystali metodę Entropii. Entropia w statystyce oznacza stopień wyjątkowości zbioru. Jest pojęciem zaczerpniętym z termodynamiki gdzie określa stopień nieuporządkowania układu. W przypadku metod wspomagających podejmowanie decyzji, metoda entropii pozwala na oszacowanie istotności analizowanych wariantów, służących do oceny wybranych wariantów, rozwiązania postawionego problemu decyzyjnego, na podstawie rozbieżności wartości każdego z nich. Po raz pierwszy metodę entropii w teorii informacji zastosował Cloude Shannon, a następnie udoskonalili B. MacMillana i L. Breimana.

W metodzie tej do końcowego etapu algorytmu obliczeń, w wyniku którego uzyskuje się preferowaną kolejność poszczególnych wariantów, wykorzystuje się następujące elementy:

- Stopnie spełnienia kryteriów określone, w sposób subiektywny, przez decydenta (eksperta)

- Stopnie spełnienia kryteriów uzyskane na podstawie procedury obliczeniowej

Przedstawiono algorytm obliczeniowy prowadzący do uzyskania wyżej wymienionych stopni ważności, które w ostateczności posłużą do wyznaczenia szeregu preferowanych rozwiązań. Artykuł zawiera przykładowe obliczenia i zwieńczony jest wnioskami. 